\title{
Spreading of Isolated Ptch Mutant Basal Cell Carcinoma Precursors Is Physiologically Suppressed and Counteracts Tumor Formation in Mice
}

\author{
Nadine Brandes (D, Slavica Hristomanova Mitkovska, Dominik Simon Botermann, \\ Wiebke Maurer, Anna Müllen, Hanna Scheile D, Sebastian Zabel, Anke Frommhold, Ina Heß, \\ Heidi Hahn (D) and Anja Uhmann* D \\ Tumor Genetics Group, Institute of Human Genetics, University Medical Center Göttingen, \\ Heinrich-Düker-Weg 12, 37079 Göttingen, Germany; nadine.brandes@med.uni-goettingen.de (N.B.); \\ s.hristomanovamitk@stud.uni-goettingen.de (S.H.M.); dominik.botermann@med.uni-goettingen.de (D.S.B.); \\ wiebke.maurer@stud.uni-goettingen.de (W.M.); anna.muellen@stud.uni-goettingen.de (A.M.); \\ hannarabe@gmx.de (H.S.); sebastian.zabel@live.de (S.Z.); anke.frommhold@med.uni-goettingen.de (A.F.); \\ ihess@gwdg.de (I.H.); hhahn@gwdg.de (H.H.) \\ * Correspondence: auhmann@gwdg.de; Tel.: +49-551-3914-100; Fax: +49-551-396-580
}

Received: 2 November 2020; Accepted: 3 December 2020; Published: 5 December 2020

\begin{abstract}
Basal cell carcinoma (BCC) originate from Hedgehog/Patched signaling-activated epidermal stem cells. However, the chemically induced tumorigenesis of mice with a CD4Cre-mediated biallelic loss of the Hedgehog signaling repressor Patched also induces BCC formation. Here, we identified the cellular origin of $C D 4 C r e$-targeted BCC progenitors as rare Keratin $5^{+}$epidermal cells and show that wildtype Patched offspring of these cells spread over the hair follicle/skin complex with increasing mouse age. Intriguingly, Patched mutant counterparts are undetectable in age-matched untreated skin but are getting traceable upon applying the chemical tumorigenesis protocol. Together, our data show that biallelic Patched depletion in rare Keratin $5^{+}$epidermal cells is not sufficient to drive BCC development, because the spread of these cells is physiologically suppressed. However, bypassing the repression of Patched mutant cells, e.g., by exogenous stimuli, leads to an accumulation of BCC precursor cells and, finally, to tumor development.
\end{abstract}

Keywords: Patched receptor; basal cell carcinoma; keratin 5; epidermal cells; epidermis; hair follicle

\section{Introduction}

Epidermal stem cells of the hair follicle (HF) outer root sheath (ORS) [1], bulge [2], secondary hair germ [3-5] and/or the interfollicular epidermis (IFE) [1,6] can give rise to basal cell carcinoma (BCC). BCC are the most frequent skin neoplasia in humans [7], with mutations in the Hedgehog (Hh)-signaling inhibitor Patched (Ptch) appearing as one of the major driving forces in the development of this tumor entity [8]. We recently showed that a CD4Cre-mediated homozygous Patched deletion (Ptchfff CD4Cre) does not affect T-cell functions in vitro and in vivo $[9,10]$ but can result in BCC formation upon treatment with 7,12-Dimethylbenz[a]anthracene (DMBA)/12-O-tetradecanoylphorbol-13-acetate (TPA) [11]. This was an unexpected observation, because $C D 4 C r e-d e l e t e r$ mice express a Cre-recombinase gene under the control of the Cluster of differentiation 4 promoter/enhancer/silencer. However, Ptch ff CD4Cre mice do not spontaneously develop BCC [11], demonstrating that homozygous Ptch depletion using the $C D 4 C$ re driver is not sufficient for BCC development. This is in contrast to BCC mouse models using "classical" BCC drivers $[4,12,13]$, in which the Ptch mutation is simultaneously induced in a large proportion of HF stem cells [4] or basal IFE cells $[1,4,13]$ and in which BCC develop spontaneously. These data suggest that the $C D 4 C$ re driver targets $B C C$ progenitors with a lower 
tumorigenic potential and/or at lower frequency compared to "classical" BCC models. However, this also opens the question whether a certain quantity of Hh-activated BCC precursors is necessary for $\mathrm{BCC}$ development, which could have far-reaching consequences for the understanding and treatment of sporadic human BCC.

We here determined the $C D 4 C r e$-targeted BCC progenitor cell type and its frequency by following the nonhematopoietic progeny of wildtype Ptch and Ptch mutant CD4Cre-targeted cells in the adult skin by lineage tracing experiments. We show that the $C D 4 C r$ re transgene is expressed in $\mathrm{K}^{+}$epidermal cells and that wildtype Ptch progenies of $\mathrm{CD} 4 \mathrm{Cre}$-targeted keratinocytes populate the adult $\mathrm{HF} / \mathrm{skin}$ complex with increasing mouse age. In contrast, Ptch mutant progenies of $\mathrm{CD} 4 \mathrm{Cre}$-targeted keratinocytes are undetectable and do not accumulate like their wildtype Ptch counterparts under normal conditions. However, the exogenous stimulation of their survival can result in BCC development. Taking together, our data demonstrate that isolated BCC precursors with a homozygous Ptch depletion do not spread or accumulate and are not sufficient for BCC development under normal conditions.

\section{Results}

2.1. Wildtype Ptch Progeny of CD4Cre-Targeted Cells Spread over the HF/Skin Complex with Increasing Mouse Age

To characterize the cellular origin of Ptchfff CD4Cre BCC, CD4Cre-targeted wildtype Ptch cells were traced in CD4Cre R26-tdT mice by their tdTomato (tdT) expression (see Appindix A, Figure A1 for tdT expression in CD4Cre R26-tdT thymus). Flow cytometric analyses revealed the existence of various tdT-expressing cell populations in back skin epidermal isolates of CD4Cre R26-tdT mice in comparison to the controls (Figure 1A,B). Based on the expression levels of tdT and the general keratinocyte marker $\mathrm{CD} 49 \mathrm{f}$, we observed three relatively stable tdT-expressing populations $\left(\mathrm{tdT}^{+} \mathrm{CD} 49 \mathrm{f}{ }^{\text {low }}\right.$, $\mathrm{tdT}^{+} \mathrm{CD} 49 \mathrm{f}$ high and td $\mathrm{T}^{\text {low }} \mathrm{CD} 49 \mathrm{f}^{\text {high }}$ ) and a td $\mathrm{T}^{\text {high }} \mathrm{CD} 49 \mathrm{f}^{\text {high }}$ population, which strongly augments with increasing mouse age (Figure $1 \mathrm{~A}, \mathrm{C})$. Further analyses revealed that the $\mathrm{tdT}^{+} \mathrm{CD} 49 \mathrm{f}^{\text {low }}$ population mainly consists of TCR $\beta-$, CD3- or CD16-expressing immune cells (Figure 2), whereas the tdT ${ }^{+}$CD49fhigh and the $\mathrm{tdT}^{\text {low }} \mathrm{CD} 49 \mathrm{f}^{\text {high }}$ populations contain small numbers of CD16-expressing (e.g., macrophages; Figure 2) or TCR $\beta$ and CD3-expressing immune cells (T cells; Figure 2), respectively (for the verification of antibody specificity, see Appendix A Figure A2). Remarkably, tdT high CD49f figh cells do not express immune cell markers (Figure 2), indicating that this population has a pure keratinocyte identity. To verify our conclusion that the number of keratinocytes descending from CD4Cre-targeted cells increases with mouse age, we analyzed whole mount preparations from the back skin of differentially aged CD4Cre R26-tdT mice. Indeed, this approach showed that the skin of aged CD4Cre R26-tdT mice contains enormous numbers of wildtype Ptch $\mathrm{tdT}^{+} \mathrm{HF}$ compared to younger mice (Figure $3 \mathrm{~A}$ ), whereas, in the third anagen of CD4Cre R26-tdT back skin (11 weeks old), only isolated tdT ${ }^{+} \mathrm{HF}_{\text {were detected; }}$ the numbers of $\mathrm{tdT}^{+} \mathrm{HF}$ increased enormously from the fourth (16 weeks old), fifth ( 25 weeks old) and to the ninth anagen (55 weeks old) (Figure $3 \mathrm{~A}$ ). Thereby, $\mathrm{tdT}^{+}$cells grow over the entire length of anagen HF (Figure 3B) and, also, in the IFE of CD4Cre R26-tdT back skin (Figure 3C), indicating that the $\mathrm{CD} 4 \mathrm{Cre}$ transgene targets cells of the HF and of the IFE compartment. 
A

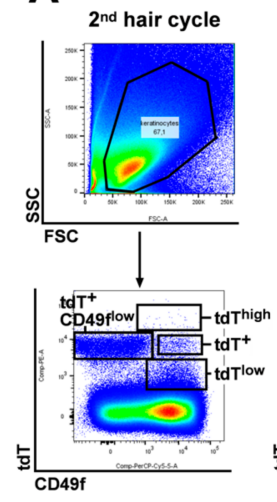

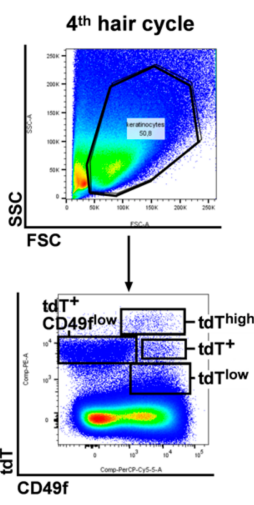

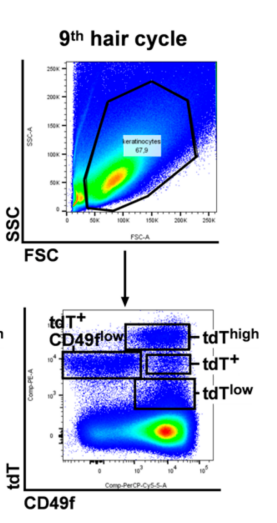

B

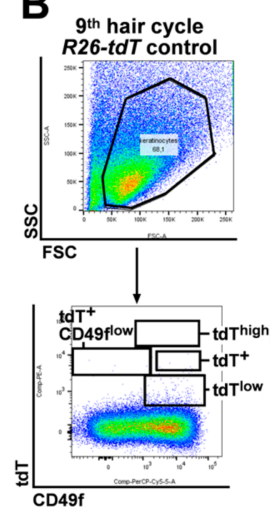

C

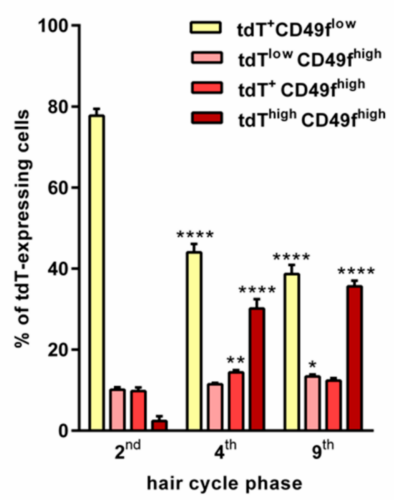

Figure 1. tdTomato (tdT) ${ }^{\text {high }} \mathrm{CD} 49 \mathrm{f}^{\text {high }}$-expressing cells accumulate in CD4Cre R26-tdT skin with increasing mouse age. (A,B) Representative flow cytometric analyses of (A) 2,500,000 CD4Cre R26-tdT back skin isolates of the 2nd, 4th and 9th telogens and (B) 1,000,000 R26-tdT control back skin isolates of the 9th telogen stained with anti-CD49f-peridinin-chlorophyll-protein (PerCP)-Cy5.5 antibodies. Top: Forward scatter (FSC)/side scatter (SSC) plots for gating on living cells. Bottom: tdT (phycoerythrin $[\mathrm{PE}]$ channel)/CD49f plots for visualization of the tdT expression on the gated living cells. In CD4Cre $R 26-t d T$ back skin isolates, 4 different tdT-expressing populations (one CD49f $\mathrm{f}^{\text {low }}$-expressing population: $\mathrm{tdT}^{+} \mathrm{CD} 49 \mathrm{f}^{\text {low }}$ and $3 \mathrm{CD} 49 \mathrm{f}^{\text {high }}$-expressing populations: $\mathrm{tdT}^{\mathrm{low}}$, $\mathrm{tdT}^{+}$and $\mathrm{tdT}^{\text {high }}$ ) were distinguishable in differential aged mice, whereas no tdT $\mathrm{T}^{+}$cells were detected in $R 26-t d T$ back skin isolates using the PE channel (B). (C) Percentage share of $\mathrm{tdT}^{+} \mathrm{CD} 49 \mathrm{f}^{\mathrm{low}}$ and $\mathrm{tdT}^{\mathrm{low}}, \mathrm{tdT}^{+}$and $\mathrm{tdT}^{\text {high }}$ cells $\left(\mathrm{N}_{2 \mathrm{nd}}=5\right.$, $\mathrm{N}_{4 \text { th }}=3$ and $\mathrm{N}_{9 \text { th }}=3$ ) at the indicated hair cycle phases (based on the flow cytometric analyses shown in (A)). Bars represent mean $+/-$ SEM. Significant differences were calculated using a nonparametric Mann-Whitney test. ${ }^{*} p>0.05,{ }^{* *} p>0.01$ and ${ }^{* * *} p>0.0001$.

\subsection{The CD4Cre-Deleter Targets Keratin $5^{+}$Epidermal Cells That Are the Origin of DMBA/TPA-Induced BCC in Ptchfff CD4Cre Mice}

Both the ORS of HF and the basal layer of the IFE are characterized by Keratin 5 (K5) expression [1]. Thus, lineage tracing of the K5 promoter-driven CreERT-recombinase expression results in the labeling of cells in both compartments [14]. Furthermore, since $\mathrm{K} 5^{+}$cells can be the origin of BCC [1] (for review, see [15]), we hypothesized that the $C D 4 C$ re transgene targets $\mathrm{K}^{+}$epidermal cells. Indeed, immunofluorescence stainings of individually isolated $\mathrm{tdT}^{+} \mathrm{HF}$ and cryo-sectioned back skin of CD4Cre $R 26-t d T$ mice revealed that $\mathrm{K}^{+}$cells of the ORS (Figure $4 \mathrm{~A}$ ), as well as of the basal layer, express tdT (Figure 4B). Moreover, in vitro cultured tdT ${ }^{\text {neg }}$ keratinocytes from CD4Cre R26-tdT back skin started to express tdT 22 days post-seeding. The subsequent immunofluorescent staining verified that all newly recombined $\mathrm{tdT}^{+}$cells express $\mathrm{K} 5$ (Figure $4 \mathrm{C}$ ). Forty-two or 55 days after seeding, $0.47 \%$ or $0.68 \%$ of all $\mathrm{K}^{+}$cells were $\mathrm{tdT}^{+}$, respectively. Based on these data, we concluded that the CD4Cre driver targets rare $\mathrm{K}^{+}$keratinocytes, which most probably are also the origin of BCC in Ptchf/f CD4Cre mice. If this is the case, the histological appearance of the DMBA/TPA-induced BCC in Ptchfff CD4Cre mice should mimic that of BCC from Ptchfff K5CreERT mice. The latter arise from the lower HF and from the IFE $[13,15]$ and express K5 (Appendix A Figure A3). However, BCC of DMBA/TPA-treated Ptchf/f CD4Cre skin (for experimental set-up, see Figure 5A) exclusively occur at the IFE in HF-near regions (Figure 5B,C) and express K5 (Figure 5C) but never grow as tumors of the bulge or secondary hair germ like in Ptchflf K5CreERT skin [13] (Appendix A Figure A3). To evaluate the possibility that the chemical treatment may preferably induce BCC development from IFE cells, we furthermore analyzed BCC from DMBA/TPA-treated heterozygous Ptch $^{+/-}$mice [16]. Contrarily to BCC in Ptchf/f CD4Cre skin, and similar to BCC from Ptch fff K5CreERT, BCC from DMBA/TPA-treated Ptch ${ }^{+/-}$mice arise from HF and IFE (Figure 5D,E; for a comparison of BCC/mm skin in DMBA/TPA-treated Ptch f/f CD4Cre and $\mathrm{Ptch}^{+/}$mice, see Appendix A Figure A4) and stain positive for K5 (Figure 5E). This shows that the origin of DMBA/TPA-induced BCC is not determined by the chemical treatment but, rather, by the 
compartment of the genetically targeted cell type, and thus, the $\mathrm{CD} 4 \mathrm{Cre}$-deleter most likely targets $\mathrm{K}^{+}$ basal cells of HF-near IFE.

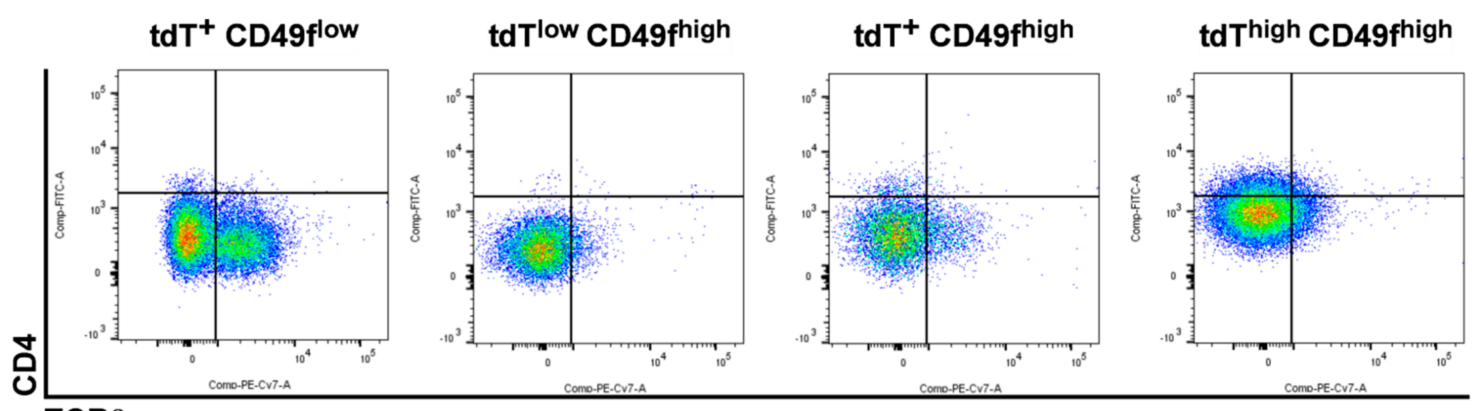

$$
\operatorname{TCR} \beta
$$
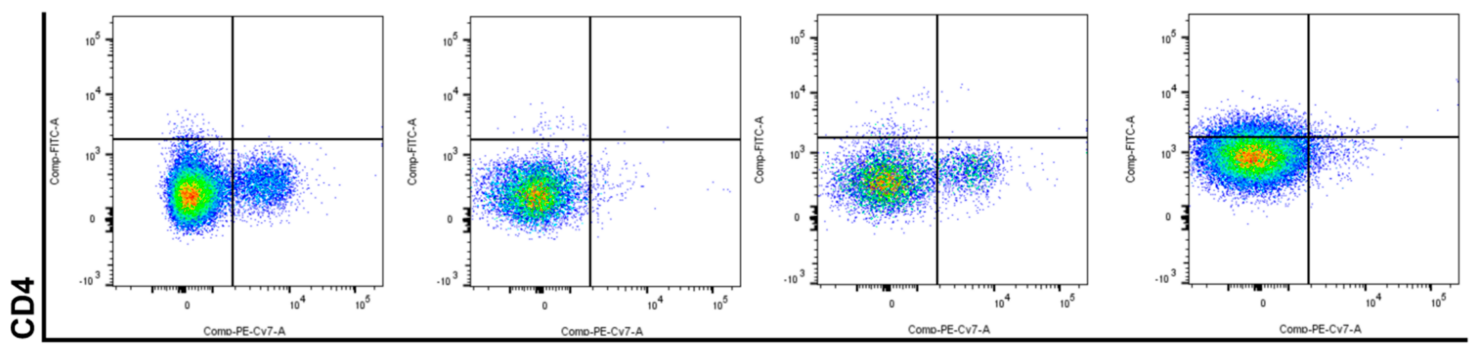

CD3
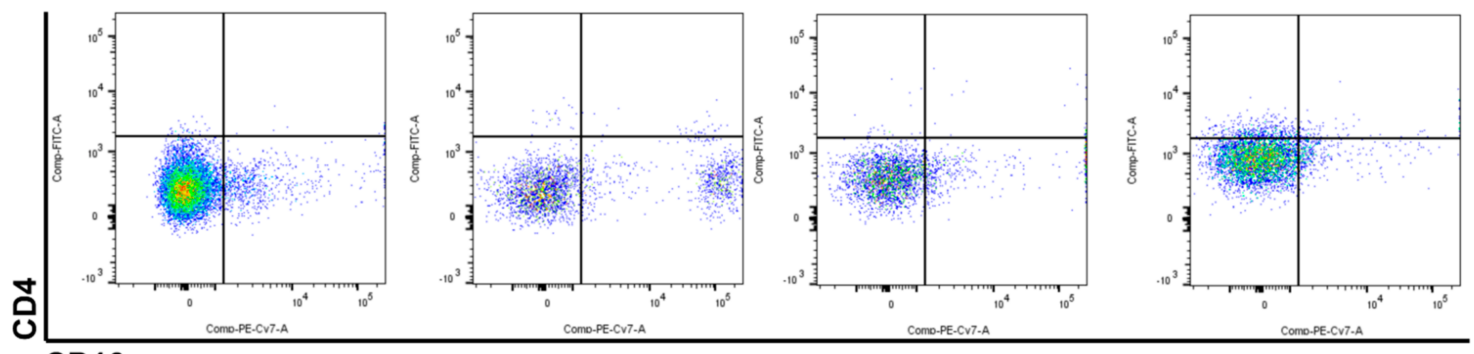

CD16

Figure 2. $\mathrm{td}^{\text {high }} \mathrm{CD} 49 \mathrm{f}^{\text {high }}$-expressing cells of aged CD4Cre R26-tdT mice do not express immune cell markers. Representative plots of flow cytometric analyses of 2,500,000 CD4Cre R26-tdT back skin isolates of the 4th telogen stained with anti-CD4-fluorescein isothiocyanate (FITC); anti-CD49f-PerCP-Cy5.5 and anti-TCR $\beta-P E-C y 7$ (top), CD3-PE-Cy7 (middle) or anti-CD16-PE-Cy7 (bottom) antibodies gated as shown in Figure 1A. Individual CD4/TCR $\beta, C D 4 / C D 3$ or CD34/CD16 analyses of the $\operatorname{tdT}^{+}$CD49flow and the $\mathrm{tdT}^{\text {low }} \mathrm{CD} 49 \mathrm{f}^{\text {high }}$, $\mathrm{tdT}^{+} \mathrm{CD} 49 \mathrm{f}^{\text {high }}$ and tdT ${ }^{\text {high }} \mathrm{CD} 49 \mathrm{f}^{\text {high }}$ subpopulations revealed $\mathrm{TCR} \beta^{+}$and $\mathrm{CD}^{+}$immune cells in the $\mathrm{tdT}^{+} \mathrm{CD} 49 \mathrm{f}^{\text {low }}$ and the $\mathrm{tdT}^{+} \mathrm{CD} 49 \mathrm{f}^{\text {high }}$ populations, whereas $\mathrm{CD} 16^{+}$immune cells were detected in the $\mathrm{tdT}^{+} \mathrm{CD} 49 \mathrm{f}^{\text {low }}$ and the $\mathrm{tdT}^{\text {low }} \mathrm{CD} 49 \mathrm{f}^{\text {high }}$ populations. $\mathrm{tdT}^{\text {high }} \mathrm{CD} 49 \mathrm{f}^{\text {high }}$ cells express none of the immune cell markers, except for a slightly increased CD4 protein level. 


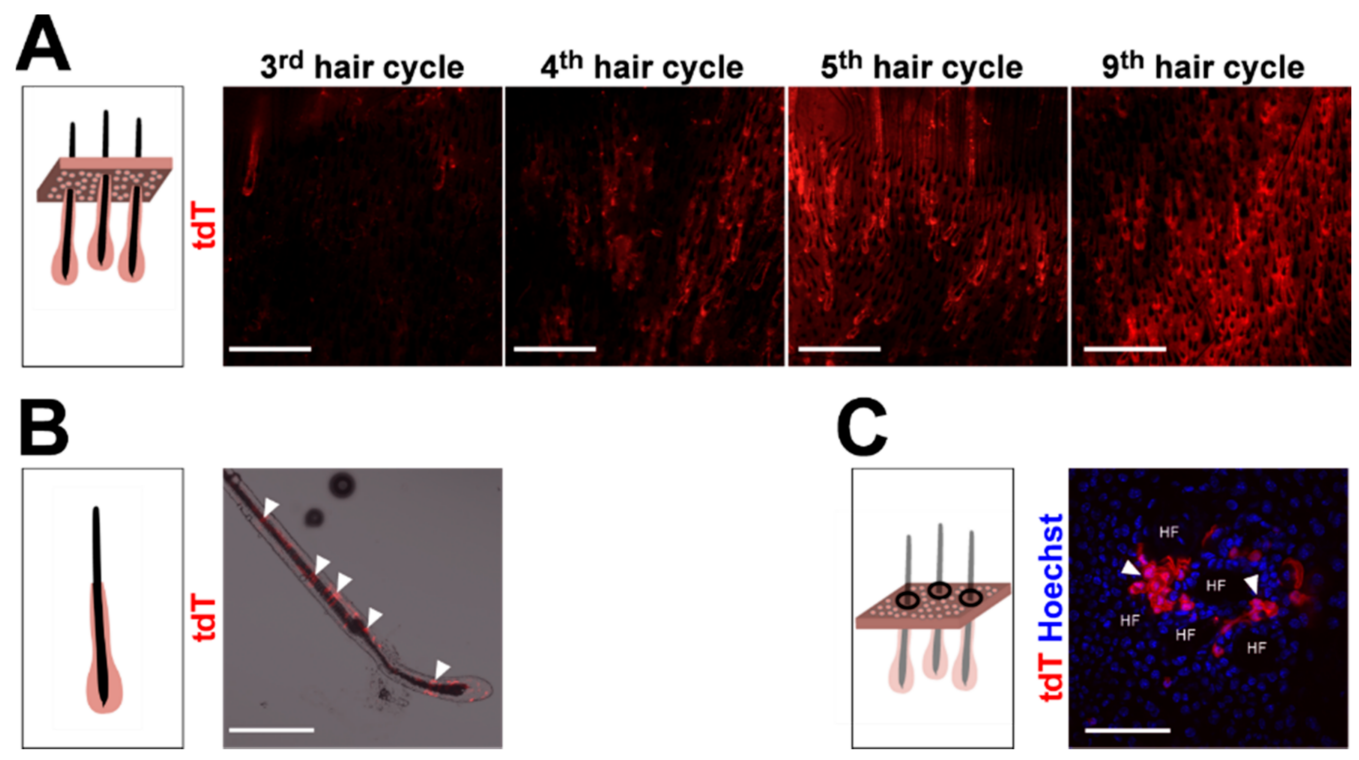

Figure 3. Wildtype Ptch $\mathrm{tdT}^{+}$cells accumulate in hair follicle (HF) and interfollicular epidermis (IFE) with increasing age of the CD4Cre R26-tdT mice. (A-C) Representative fluorescent analyses of (A) epidermal sheets of the back skin of CD4Cre R26-tdT mice at the indicated hair cycles (dermal view), (B) an individually isolated HF of the back skin of a CD4Cre R26-tdT mouse and (C) an epidermal preparation at late-anagen of the back skin of a CD4Cre R26-tdT mouse (top view). Scale bars: $1 \mathrm{~mm}$ (A) and $100 \mu \mathrm{m}(\mathbf{B}, \mathbf{C})$.

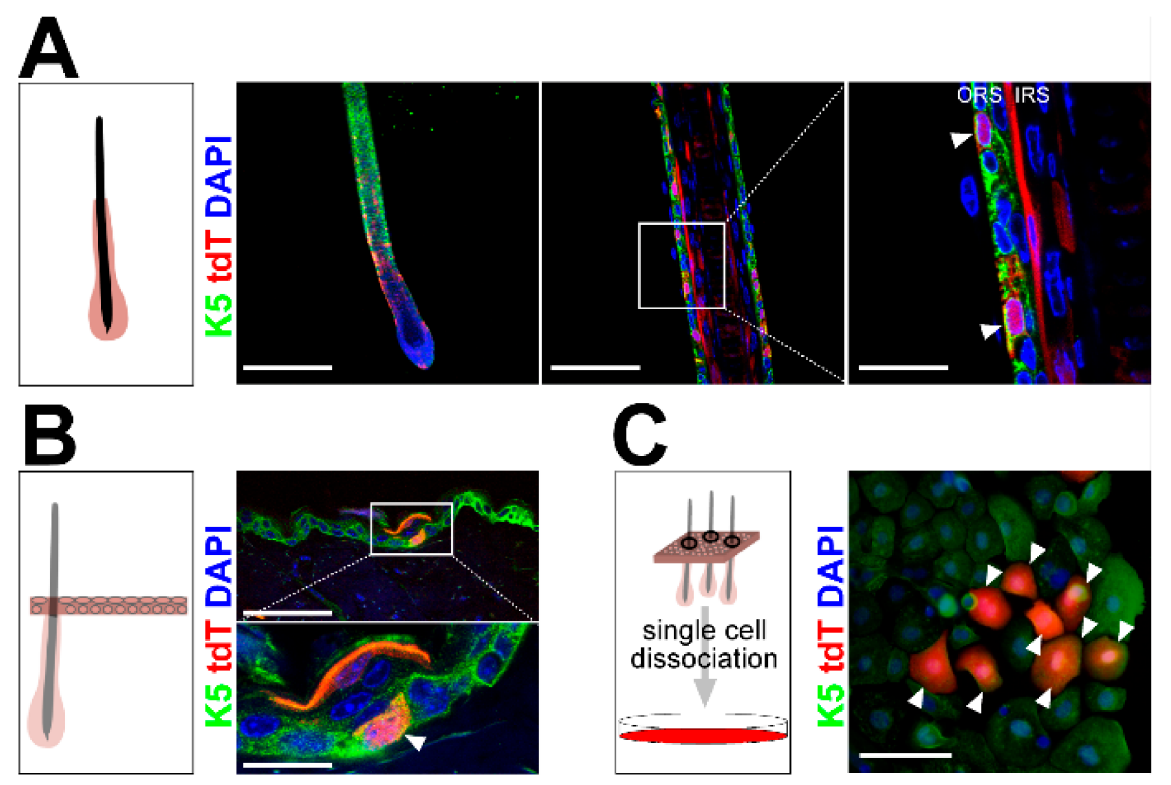

Figure 4. Wildtype Ptch $\mathrm{tdT}^{+}$cells of CD4Cre R26-tdT back skin descents from CD4Cre-targeted rare $\mathrm{K} 5^{+}$epidermal cells. (A,B) Representative fluorescent analyses of (A) an individually isolated HF of back skin and (B) cryo-sectioned back skin of CD4Cre R26-tdT mice stained against K5. (C) In vitro cultured tdT ${ }^{\text {neg }}$ epidermal cells of $C D 4 C r e$ R26-tdT back skin 55 days post-seeding stained against the outer root sheath (ORS) and basal cell marker $\mathrm{K} 5 . \mathrm{tdT}^{+} \mathrm{K} 5^{+}$double-positive cells are marked with arrow heads. Box: zoomed area. IRS: inner root sheath. Scale bars: $100 \mu \mathrm{m}(\mathbf{A}$, left and $\mathbf{C}), 33 \mu \mathrm{m}$ (A, middle and $\mathbf{B}$, top) and $10 \mu \mathrm{m}$ (A, right). 
A

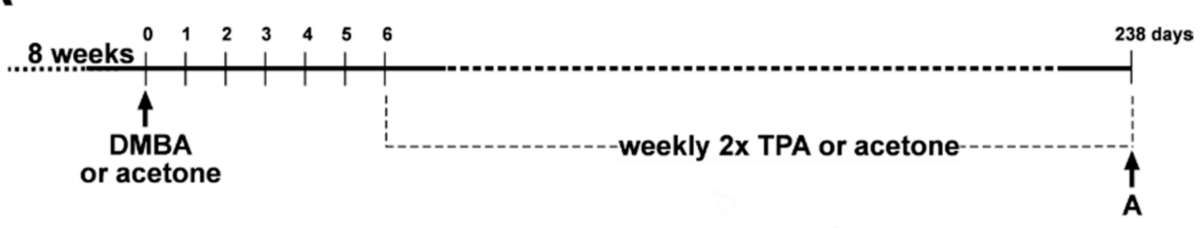

B CD4Cre Ptchfff DMBA/TPA

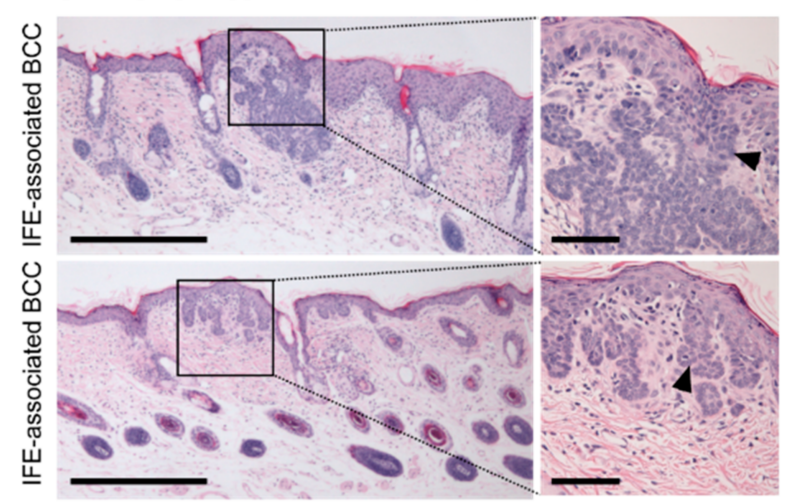

C

\section{Ptch $^{+/}$DMBA/TPA}
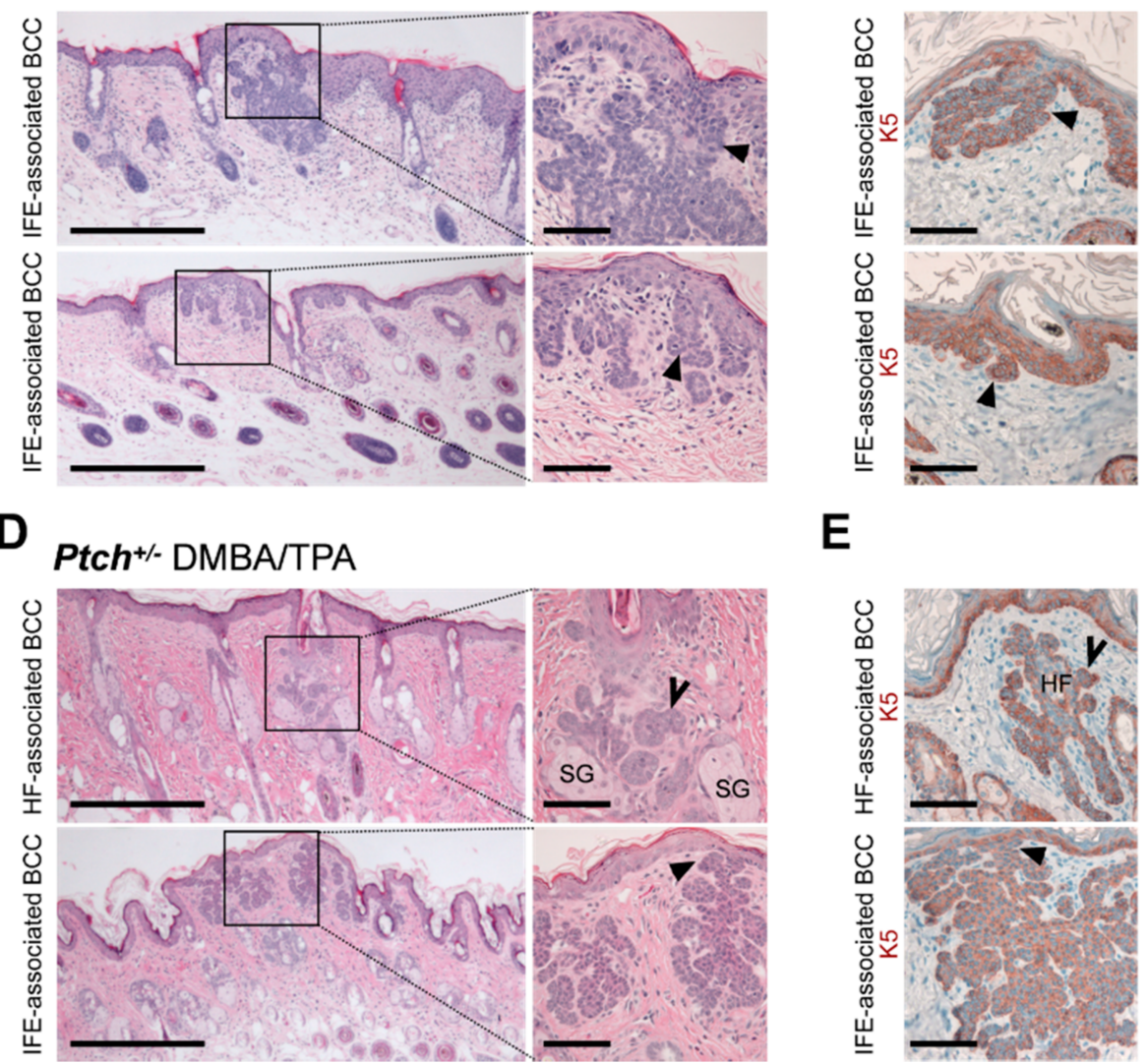

E

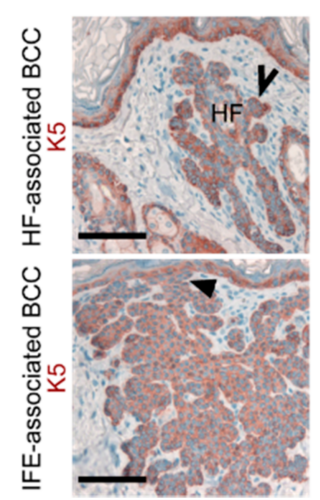

Figure 5. Basal cell carcinoma (BCC)-like tumors of 7,12-Dimethylbenz[a]anthracene (DMBA)/12-O-tetradecanoylphorbol-13-acetate (TPA)-treated Ptchfff CD4Cre skin appear exclusively IFE-associated. (A) Experimental set-up of the DMBA/TPA carcinogenesis protocol. (B-E) Representative hematoxylin and eosin (H\&E) stainings (B,D) and anti-K5 antibody stainings (C,E) of BCC from 42-week-old DMBA/TPA-treated Ptchfff CD4Cre (B,C) and Ptch ${ }^{+/-}$back skin (D,E) $\left(\mathrm{N}_{\text {Ptchfff } C D 4 C r e}=13\right.$ and $\left.\mathrm{N}_{\text {Ptch }+/-}=8\right)$. Solid arrows: BCC associated to the IFE; open arrows: BCC associated to HF. HF: hair follicle, SG: sebaceous gland. Boxes: zoomed areas. Scale bars: $20 \mu \mathrm{m}(\mathbf{B}$, left and D, left) and $100 \mu \mathrm{m}(\mathbf{B}$, right, $\mathbf{C}$ and $\mathbf{D}$, right and $\mathbf{E})$.

\subsection{Isolated Ptch Mutant Epidermal Cells do Not Spread Like Their Wildtype Ptch Counterparts}

The CD4Cre-deleter targets rare K5-expressing epidermal IFE cells, in which a biallelic Ptch mutation did not, per se, result in $\mathrm{BCC}$ formation. This indicates that the quantity of $\mathrm{K}^{+}$Ptch mutant BCC precursors in untreated Ptchfff CD4Cre skin is not sufficient for spontaneous BCC development, as seen in Ptchfff K5CreERT mice. However, our lineage-tracing analyses showed that robust numbers of wildtype Ptch epidermal keratinocytes descending from CD4Cre-trageted cells grow in the skin of aged mice. Thus, one could speculate that the numbers of Ptch mutant keratinocytes growing in the skin of aged Ptchfff CD4Cre mice are comparable, which would oppose the assumption that a low quantity of $\mathrm{K}^{+}$Ptch mutant BCC precursor is not sufficient for BCC development. To shed light on this discrepancy, we traced Ptch mutant progenies of CD4Cre-targeted cells in R26-LacZ Ptch ff CD4Cre skin. Remarkably, and in contrast to wildtype Ptch skin (Figure 6A), this approach revealed that HF 
and IFE of 42-week-old R26-LacZ Ptchff CD4Cre mice (Figure 6B), as well as of R26-LacZ Ptch fff CD4Cre mice transplanted with wildtype Ptch bone marrow (Figure 6C), are completely free of progenies of CD4Cre-targeted cells (control LacZ stainings, Appendix A Figure A5). In contrast, DMBA/TPA-treated R26-LacZ Ptch fff CD4Cre skin shows Ptch mutant LacZ ${ }^{+}$HF (Figure 6B) but at much lower numbers compared to the skin of age-matched untreated $C D 4 C r e ~ R 26-t d T$ mice, which show numerous wildtype Ptch $\mathrm{tdT}^{+} \mathrm{HF}$ (Figure 6A). Anti-K5 antibody staining furthermore revealed that the few $\mathrm{LacZ}^{+}$cells in HF and HF-near IFE of DMBA/TPA-treated R26-LacZ Ptch fff CD4Cre skin are positive for K5 or at least descend from $\mathrm{K}^{+}$cells (e.g., suprabasal layers of the IFE) (Figure 6D).

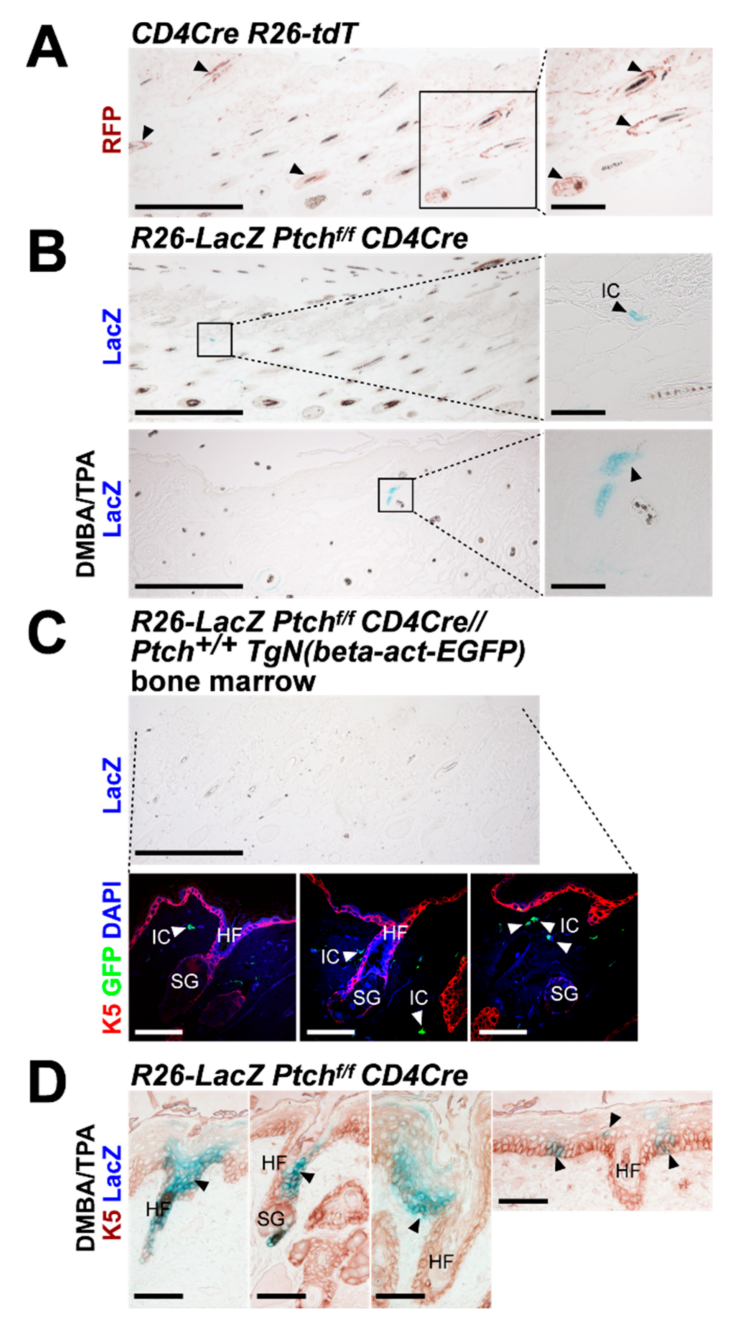

Figure 6. Ptch mutant descendants of CD4Cre-targeted epidermal cells do not populate the skin with increasing mouse age like their wildtype Ptch counterparts. (A,B) Representative anti-red fluorescent protein (RFP)-stained paraffin sections of (A) CD4Cre R26-tdT back skin and (B) LacZ-stained untreated (top) and DMBA/TPA-treated (bottom) R26-LacZ Ptchfff CD4Cre back skin at an age of 42 weeks $\left(\mathrm{N}_{C D 4 C r e ~ R 26-t d T}=7 ; \mathrm{N}_{R 26-L a c Z \text { Ptchfff CD4Cre }}=6\right)$. The tdT protein was visualized using an anti-RFP antibody. (C) Representative anti-K5/anti-green fluorescent protein (GFP) antibody/LacZ-stained paraffin sections of untreated back skin of a R26-LacZ Ptchflf CD4Cre mouse adoptively transplanted with wildtype Ptch TgN(beta-act-EnhancedGFP) bone marrow at an age of 42 weeks (30 weeks after transplantation). (D) Representative anti-K5 antibody/LacZ-stained paraffin sections of DMBA/TPA-treated R26-LacZ Ptchfff CD4Cre back skin at an age of 42 weeks. Black arrow heads: $\mathrm{tdT}^{+} \mathrm{LacZ}^{+}$or double-positive cells/areas and white arrow heads: $\mathrm{GFP}^{+}$immune cells. Boxes: zoomed areas. IC: immune cells; HF: hair follicle; SG, sebaceous gland. Scale bars: $20 \mu \mathrm{m}$ (A, left, B, left and D, top); $100 \mu \mathrm{m}$ (A, right, B, right and $\mathbf{C})$ and $33 \mu \mathrm{m}$ (D, bottom). 
These findings indicate that isolated Ptch mutant descendants from $\mathrm{K}^{+}$epidermal cells do not contribute to normal skin homoeostasis, since the spreading of these rare epidermal cells (e.g., of CD4Cre-targeted cells) is suppressed under physiological conditions. Thus, as a result, the probability of spontaneous BCC development is strongly reduced in Ptch fff CD4Cre skin. In addition, whereas the Ptch status of T cells does not influence this phenomenon, the DMBA/TPA treatment seems to enhance the survival probability of Ptch mutant $\mathrm{K}^{+}$epidermal cells and their offspring, which, finally, can result in BCC formation.

\section{Discussion}

The development of BCC is closely related to Ptch mutations and the subsequent activation of $\mathrm{Hh} / \mathrm{Ptch}$ signaling in stem cells of the HF and the IFE [8]. However, genome-sequencing data from human BCC samples hint towards a more complex pathway interaction in BCC development [17]. In line with this assumption, our novel data show that homozygous Ptch depletion in rare $\mathrm{K}^{+}$ epidermal cells is insufficient to drive BCC formation in mice, most likely due to the physiological erasure of the mutant cells.

In the skin, as an organ prone for Hh/Ptch-associated BCC development, a biallelic Ptch mutation, which occurs simultaneously in all stem cells of the HF or of the IFE, leads to BCC formation $[4,13]$. Thus, the lack of a spontaneous BCC development in Ptchfff CD4Cre mice, together with our novel results that wildtype Ptch $C D 4 C r e$-targeted epidermal cells widely populate the HF/skin complex, were puzzling. However, our data also revealed that neither untreated nor DMBA/TPA-treated Ptchfff $C D 4 C r e$ skin contains comparable amounts of $C D 4 C r e$-targeted offspring, as seen in aged wildtype Ptch skin. Thus, under normal physiological conditions, BCC development in Ptchfff CD4Cre skin seems to be repressed by the physiological inhibition of the spreading of rare Ptch mutant epidermal cells. Since CD4Cre-mediated Ptch depletion does not affect T cell (e.g., cytotoxic T cells [CTL]) function in vivo [9,10], and wildtype Ptch bone marrow transplantation does not induce a spread of Ptch mutant keratinocytes in Ptchfff CD4Cre mice [11] (see Figure 6C), an immune cell-mediated suppression of Ptch mutant keratinocytes can be excluded. However, hypothetically, an epithelial defense against cancer (EDAC), which is based on cell competition between cells of different fitness [18], might mediate the inhibition of Ptch mutant keratinocyte spreading. One major prerequisite for the elimination of less fit cells (or mutant cells) by EDAC is that the genetically altered ones are surrounded by wildtype cells [18]. This is most likely the case for Ptch mutant epidermal cells in Ptchfff CD4Cre skin. However, various parameters (e.g., ratio of normal/transformed cells and environmental factors) can affect the EDAC and potentially convert the antitumorigenic process to a super-competition, in which cells with an accumulation of a series of oncogenic mutations outcompete normal or single-mutant cells [18]. Indeed, we observed that the DMBA/TPA treatment of R26-LacZ Ptchfff CD4Cre skin increases the probability to detect $\mathrm{LacZ}^{+}$Ptch mutant epidermal cell clusters in isolated HF and IFE areas that have not yet developed to BCC. These observations indicate that the chemicals confer a survival benefit of the rare Ptch mutant $\mathrm{K}^{+}$epidermal cells in Ptchfff $\mathrm{CD} 4 \mathrm{Cre}$ skin, which might be due to an accumulation of oncogenic mutations and the suppression of normal cells. Probably, aberrant Ras signaling does not play a role in DMBA/TPA-induced BCC development in Ptchfff CD4Cre mice [11], while the disruption of physiological apoptotic responses via the DMBA/TPA-mediated downregulation of p53 [19] is more likely [12,20,21]. Moreover, the induction of apoptosis in BCC cells, e.g., by Fas upregulation, reduces the development and the size of UV light-induced BCC [20]. Hence, in the case of a homozygous Ptch mutation in isolated BCC precursors, the DMBA/TPA treatment, similarly to UV light exposure $[15,22,23]$, potentially may abrogate apoptotic processes, which normally can erase isolated Ptch mutant cells from the skin. Subsequently, Ptch mutant epidermal cells are multiplied, accumulate additional mutations and, thus, are predisposed to BCC development. Indeed, Ptch heterozygous SKH1 Hairless mice progressively develop spontaneous BCC, which are further boosted by UV light exposure. This suggests that, irrespective of aberrant $\mathrm{Hh} / \mathrm{Ptch}$ signaling, age-related effects (e.g., altered DNA damage responses) play a crucial role in BCC formation [22,23]. 
The fact that a homozygous Ptch mutation in isolated $\mathrm{K}^{+}$epidermal cells is not sufficient for BCC development also questions the current BCC therapy based on Hh signaling inhibitors (e.g., vismodegib). Whereas these inhibitors only target $\mathrm{Hh} / \mathrm{Ptch}$ signaling and suppress the growth of the initial BCC precursor cell, they will not target secondly accumulated tumor-promoting cascades. Indeed, cessation of the vismodegib treatment of Ptch/p53-mutant BCC not only leads to a loss of Hh-signaling marker gene expression but, also, to changes of HF stem cell-like to IFE- and isthmus-like expression profiles of the remaining BCC [21]. In humans, these inhibitors can lead to the development of BCC-adjacent cSCC (cutaneous squamous cell carcinoma) [24-26], which show decreased Hh/Ptch but increased Ras/MAPK signaling [27]. Moreover, the genetic differences of pretreatment BCC and post-treatment CSCC are minor (3\%) [27], and mutations associated with cSCC development (e.g., in effectors of the Hippo-YAP pathway and in MYCN) [28-31] have also been identified in BCC [17]. This strongly argues for a scenario in which a complex pathway interaction drives the BCC development. Such a scenario is also supported by our data demonstrating that the spread of isolated biallelic Ptch mutant BCC precursors is suppressed under normal conditions (potentially by an EDAC) and that they only develop into BCC upon a second nonphysiological stimulus. Moreover, in light of the recently made postulation that, in human skin, spatial relationships and competitive behaviors amongst clones act as suppressors of malignant progression [32], the Ptch fff CD4Cre BCC mouse model is more closely related to the human situation than "classical" BCC mouse models. This is due to the fact that the $\mathrm{CD} 4 \mathrm{Cre}$-deleter targets only single $\mathrm{K}^{+}$epidermal cells, whereas "classical" skin-specific drivers target all or large proportions of HF stem cells and/or basal cells simultaneously $[4,13]$. Thus, new BCC models such as Ptch ff CD4Cre mice will not only allow to investigate BCC-initiating events beyond Hh/Ptch-signaling activation but, also, to develop new BCC treatment options.

\section{Materials and Methods}

\subsection{Mice}

All animal experiments were performed in compliance with German legal and ethical requirements and were approved by the Lower Saxony State Office for Consumer Protection and Food Safety (file numbers 33.9-42502-04-15/1926 from November 2015, 33.9-42502-04-11/0374 from April 2011 and 33.14-42502-04-100/07 from January 2008). The following mouse strains were used: $\mathrm{Tg}$ (Cd4-cre)1Cwi/Bflu

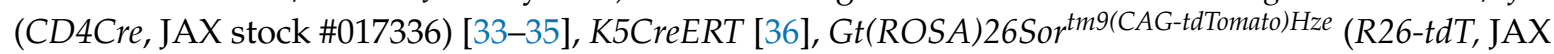

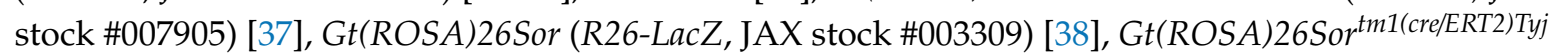
(R26-CreERT2, JAX stock \#008463) [39], TgN(beta-act-EGFP) [40], Ptch1 ${ }^{\text {tm1Zim }}$ (Ptch $^{+-}$) [41] and Ptch1 ${ }^{\text {tm1Hahn }}$ (Ptch ff, JAX stock \#012457) [42]. All used mouse strains were maintained on a C57BL/6 background. Genotyping was conducted by PCR on genomic DNA isolated from tail biopsies using primer pairs recommended by the providing scientists or by The Jackson Laboratory. Both genders of transgenic mice were used. No sex-specific differences were observed.

R26-LacZ and R26-CreERT2 mice were intraperitoneally (i.p.) injected with 1-mg tamoxifen in sunflower oil for 5 consecutive days at an age of 8 weeks [42]. DMBA/TPA treatment (Sigma-Aldrich Inc., St. Louis, MO, USA) and adoptive bone marrow transfer to irradiated mice were described previously [11].

\subsection{Isolation of Keratinocytes, Epidermal Sheets and Individual Hair Follicles}

Murine epidermal cells for flow cytometric analyses and in vitro culture were isolated using thermolysin as previously described [11]. Epidermal sheets of murine back skin and individual HF were isolated according to $[43,44]$, respectively.

\subsection{Tissue Embedding and Sectioning}

Tissue samples were fixed in $4 \%$ paraformaldehyde/1x phosphate buffered saline (PBS) at $4{ }^{\circ} \mathrm{C}$ for 2 or 3 days and, depending on the subsequent analyses, either dehydrated and embedded in 
paraffin or equilibrated overnight in $20 \%$ sucrose/1x PBS at $4{ }^{\circ} \mathrm{C}$ and embedded in cryo-medium (Medite, Burgdorf, Germany). Paraffin-embedded or cryo-embedded samples were sectioned using a microtome or a cryotome, respectively, and used for antibody or H\&E staining.

\subsection{Primary Keratinocyte Culture}

For primary keratinocyte culture, epidermal cells were isolated from telogen back skin of 19-week-old mice and were cultured under feeder-free conditions on collagen-coated dishes (Bovine Collagen Solution Type I, Sigma Aldrich Inc., St. Louis, MO, USA) in defined keratinocyte-serum-free medium (DK-SFM) basal medium (supplemented with DK-SFM growth supplements, Thermo Fisher Scientific, Waltham, MA, USA) for up to 55 days without passaging.

\subsection{LacZ Staining, Antibody Staining, Flowcytometric Analyses and Microscopy}

LacZ( $\beta$-galactosidase-) staining of tissue samples, immunohistological and immunofluorescent antibody stainings of paraffin and cryotome sections and fixed in vitro cultured cells, as well as flow cytometric analyses of keratinocytes, were described previously [11,45,46]. For antibody staining of individual HF, the samples were blocked for $30 \mathrm{~min}$ in $0.2 \%$ I-Block (Applied Biosystems, Foster City, CA, USA) and stained overnight at $4{ }^{\circ} \mathrm{C}$ with primary antibodies in $1 \times$ tris buffered saline (TBS) $/ 0.1 \%$ triton X-100, followed by a 4-h washing step in $1 \times \mathrm{TBS} / 0.1 \%$ triton $\mathrm{X}-100$. Samples were incubated overnight at $4{ }^{\circ} \mathrm{C}$ with secondary antibodies in $1 \times \mathrm{TBS} / 0.1 \%$ triton $\mathrm{X}-100$ and washed $4 \times$ for $1 \mathrm{~h}$ in $1 \times \mathrm{TBS} / 0.1 \%$ triton $\mathrm{X}-100$.

Fluorescent or immunohistological stainings or whole-organ analyses were documented on a confocal laser scanning microscope equipped with the software FluoView FV100 (Olympus Corporation, Shinjuku, Japan), Olympus BX60 microscope equipped with cellSense software or a fluorescent dissecting microscope (Leica M205FA) equipped with a digital camera (Leica DFC 450C) and the software Leica Application Suite, respectively. Flow cytometric analyses were conducted on a LSR II flow cytometer (BD Biosciences Pharmingen, San Jose, CA, USA). Data acquisition and analyses were performed using BD FacsDiva (BD Biosciences Pharmingen, USA) and FlowJo (Treestar, Ashland, OR, USA) software. If not otherwise stated, for each analysis, $2.5 \times 10^{6}$ keratinocytes were counted. For quantification of $\operatorname{td}^{\text {low }} \mathrm{CD} 49 \mathrm{f}^{\text {high }}$, $\mathrm{tdT}^{+} \mathrm{CD} 49 \mathrm{f}^{\text {high }}$ and $\mathrm{td} \mathrm{T}^{\text {high }} \mathrm{CD} 49 \mathrm{f}^{\mathrm{high}}$ cell numbers, anti-CD49f-PerCP-Cy5.5 antibody-stained back skin isolates of differentially aged CD4Cre R26-tdT mice $\left(\mathrm{N}_{2 \text { nd hair cycle }}=5, \mathrm{~N}_{4 \text { th hair cycle }}=3\right.$ and $\left.\mathrm{N}_{9 \text { th hair cycle }}=3\right)$ were analyzed by flow cytometry. Used antibodies, antibody concentrations and retrieval methods are summarized in Appendix A Tables A1 and A2.

\section{Conclusions}

The spread of rare Ptch mutant $\mathrm{K}^{+}$epidermal stem cells is physiologically suppressed. These cells only progress to BCC upon events that counteracted this suppression. These findings strengthen the more recent assumption that BCC rather develop due to a complex pathway interaction than to sole $\mathrm{Hh} / \mathrm{Ptch}$-signaling overactivation. Additionally, it indicates that mouse models for targeting isolated stem cells of the skin are needed to more precisely reflect sporadic human BCC development, which will help to better understand BCC-initiating events and to develop new, targeted BCC treatment options.

Author Contributions: N.B.: Conception and design, collection and/or assembly of data, data analysis and interpretation, visualization, manuscript writing and final approval of the manuscript; S.H.M.: collection and/or assembly of data; D.S.B.: collection and/or assembly of data; W.M.: collection and/or assembly of data; A.M.: collection and/or assembly of data; H.S.: collection and/or assembly of data; S.Z.: collection and/or assembly of data; A.F.: collection and/or assembly of data; I.H.: collection and/or assembly of data; H.H.: provision of study material and manuscript writing and A.U.: conception and design, financial support, administrative support, provision of study material, supervision, collection and/or assembly of data, data analysis and interpretation, visualization, manuscript writing and final approval of the manuscript. All authors reviewed the manuscript. All authors have read and agreed to the published version of the manuscript.

Funding: This work was supported by grant UH227-7/1 of the Deutsche Forschungsgemeinschaft to A.U. 
Acknowledgments: We are grateful for the excellent animal care by the animal caretakers and veterinarians of the Zentrale Tierexperimentelle Einrichtung of the University Medical Center, Göttingen, Germany. We furthermore thank the members of the Department of Cellular and Molecular Immunology for the opportunity to conduct flow cytometry.

Conflicts of Interest: The authors declare no conflict of interest.

\section{Abbreviations}

$\begin{array}{ll}\text { AEC } & \text { 3-amino-9-ethylcarbazole } \\ \text { BCC } & \text { basal cell carcinoma } \\ \text { cSCC } & \text { cutaneous squamous cell carcinoma } \\ \text { CTL } & \text { cytotoxic T cells } \\ \text { DK-SFM } & \text { defined keratinocyte-serum-free medium } \\ \text { DMBA } & \text { 7,12-Dimethylbenz[a]anthracene } \\ \text { DN } & \text { double-negative } \\ \text { DP } & \text { double-positive } \\ \text { EDAC } & \text { epithelial defense against cancer } \\ \text { EGFP } & \text { enhanced GFP } \\ \text { FITC } & \text { fluorescein isothiocyanate } \\ \text { FSC } & \text { forward scatter } \\ \text { GFP } & \text { green fluorescent protein } \\ \text { H\&E } & \text { hematoxylin and eosin } \\ \text { HF } & \text { hair follicle } \\ \text { Hh } & \text { hedgehog } \\ \text { IFE } & \text { interfollicular epidermis } \\ \text { IRS } & \text { inner root sheath } \\ \text { K5 } & \text { Keratin 5 } \\ \text { ORS } & \text { outer root sheath } \\ \text { PBS } & \text { phosphate buffered saline } \\ \text { PE } & \text { phycoerythrin } \\ \text { PerCP } & \text { peridinin-chlorophyll-protein } \\ \text { Ptch } & \text { Patched } \\ \text { RFP } & \text { red fluorescent protein } \\ \text { SG } & \text { sebaceous gland } \\ \text { SP } & \text { single-positive } \\ \text { SSC } & \text { side scatter } \\ \text { TBS } & \text { tris buffered saline } \\ \text { TCR } & \text { T cell receptor } \\ \text { tdT } & \text { tdTomato } \\ \text { TPA } & \text { 12-O-tetradecanoylphorbol-13-acetate } \\ & \end{array}$

\section{Appendix A}

Table A1. Primary and secondary antibodies used for immunohistochemical or immunofluorescent stainings of individual isolated hair follicles, in vitro cultured cells and paraffine or cryotome sections.

\begin{tabular}{|c|c|c|c|c|c|c|}
\hline Antigen & Antibody & Reactivity & $\begin{array}{l}\text { Manufacturer } \\
\text { (Clone) }\end{array}$ & $\begin{array}{l}\text { Antigen } \\
\text { Retrieval }\end{array}$ & Dilution & $\begin{array}{l}\text { Fluorochrome-Labeled } \\
\text { Secondary Antibody } \\
\text { (Dilution, Manufacturer, } \\
\text { Catalogue Code) }\end{array}$ \\
\hline GFP & $\mathrm{g}$ anti-GFP & & $\begin{array}{c}\text { Novus Biologicals, } \\
\text { Littleton, CO, USA } \\
\text { (NB100-1770) }\end{array}$ & $\begin{array}{l}\text { citric acid, } \\
\text { pH6 }\end{array}$ & $1: 200$ & $\begin{array}{c}\text { bov anti-gt-Alexa488 (1:200; } \\
\text { Jackson ImmunoResearch } \\
\text { Laboratories, Inc., West } \\
\text { Grove, PA, USA; } \\
\text { \#805-545-150) }\end{array}$ \\
\hline
\end{tabular}


Table A1. Cont.

\begin{tabular}{|c|c|c|c|c|c|c|}
\hline Antigen & Antibody & Reactivity & $\begin{array}{l}\text { Manufacturer } \\
\text { (Clone) }\end{array}$ & $\begin{array}{l}\text { Antigen } \\
\text { Retrieval }\end{array}$ & Dilution & $\begin{array}{l}\text { Fluorochrome-Labeled } \\
\text { Secondary Antibody } \\
\text { (Dilution, Manufacturer, } \\
\text { Catalogue Code) }\end{array}$ \\
\hline K5 & rb anti-K5 & $\mathrm{m} / \mathrm{h}$ & $\begin{array}{l}\text { Bio Legend, San } \\
\text { Diego, CA, USA } \\
\quad \text { (Poly19055) }\end{array}$ & $\begin{array}{l}\text { citric acid, } \\
\text { pH6 }\end{array}$ & 1:1000 & $\begin{array}{c}\text { d anti-rb-Alexa488 (1:200; } \\
\text { Jackson ImmunoResearch; } \\
\text { \#711-545-152) } \\
\text { d anti-rb-Cy3 (1:400; } \\
\text { Jackson ImmunoResearch; } \\
\quad \text { \#711-165-152) }\end{array}$ \\
\hline $\mathbf{R F P} *$ & $\mathrm{~g}$ anti-RFP & & $\begin{array}{c}\text { My BioSource, San } \\
\text { Diego, CA, USA } \\
\text { (MBS448122) }\end{array}$ & $\begin{array}{l}\text { boric acid or } \\
\text { citric acid, } \\
\text { pH6 }\end{array}$ & $1: 200$ & $\begin{array}{c}\mathrm{d} \text { anti-g-FITC (1:200; } \\
\text { Jackson ImmunoResearch; } \\
\text { \#705-095-147) } \\
\text { bovine anti-g-Alexa488 } \\
\text { (1:1000, Jackson } \\
\text { ImmunoResearch; } \\
\text { \#805-545-150) }\end{array}$ \\
\hline $\mathbf{R F P} *$ & rb anti-RFP & & $\begin{array}{c}\text { Rockland } \\
\text { Immunochemicals, } \\
\text { Inc., Gilbertsville, } \\
\text { PA, USA } \\
(600-401-379 S)\end{array}$ & $\begin{array}{l}\text { boric acid or } \\
\text { citric acid, } \\
\text { pH6 }\end{array}$ & $1: 500$ & $\begin{array}{c}\text { d anti-rb-Cy3 (1:400; } \\
\text { Jackson ImmunoResearch; } \\
\text { \#711-165-152) g anti-rb-Cy3 } \\
\text { (1:400; Jackson } \\
\text { ImmunoResearch; } \\
\text { \#111-165-003) }\end{array}$ \\
\hline
\end{tabular}

* detects tdTomato; m: mouse, $\mathrm{r}$ : rat; rb: rabbit; g: goat; $\mathrm{d}$ : donkey and bov: bovine. Immunohistological stainings were visualized using the EnVision system (Agilent Technologies, Santa Clara, CA, USA) and 3-amino-9-ethylcarbazole (AEC) chromogen.

Table A2. Antibodies used for flow cytometry.

\begin{tabular}{|c|c|c|c|}
\hline Antigen & Antibody & Reactivity & Clone/Catalogue Code \\
\hline CD16/CD32 & $\begin{array}{c}\mathrm{r} \\
\text { anti-CD16/CD32-PE_Cy7 }\end{array}$ & $\mathrm{m}$ & $2.4 \mathrm{G} 2$ \\
\hline $\mathrm{CD} 3 \varepsilon$ & ha anti-CD3e-PE-Cy7 & $\mathrm{m}$ & $145-2 \mathrm{C} 11$ \\
\hline CD4 & r anti-CD4-FITC & $\mathrm{m}$ & RM4-5 \\
\hline CD49f & $\begin{array}{c}\mathrm{r} \\
\text { anti-CD49f-PerCP-Cy5.5 }\end{array}$ & $\mathrm{m} / \mathrm{h}$ & $\mathrm{GoH} 3$ \\
\hline TCR $\beta$ & ha anti-TCR $\beta$-PE-Cy7 & $\mathrm{m}$ & H57-597 \\
\hline
\end{tabular}

All antibodies were purchased from BD Bioscience. m: mouse, r: rat, ha: hamster and h: human.
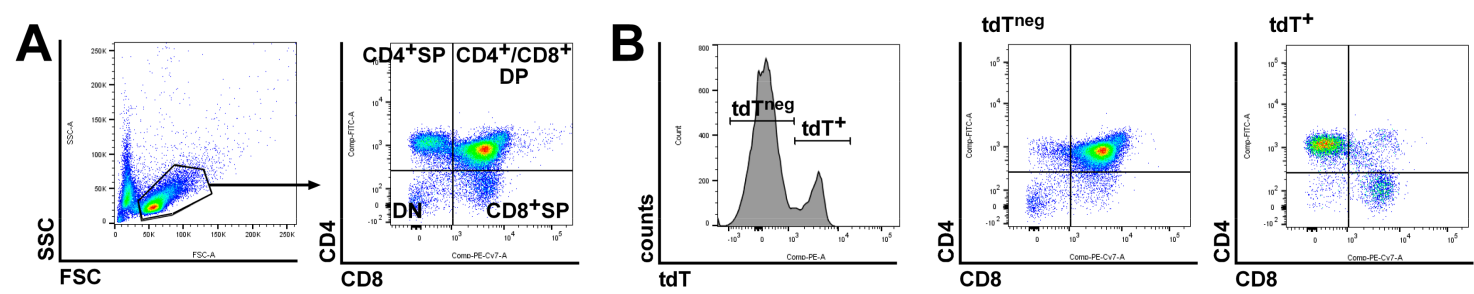

Figure A1. Flow cytometric analysis of CD4Cre R26-tdT thymocytes. (A,B) Representative flow cytometric analyses of CD4Cre R26-tdT thymocytes stained with anti-CD4-FITC and anti-CD8-PerCP-Cy7 antibodies. (A) FSC/SSC plot for gating on thymocytes (left) and CD4/CD8 plot of the gated thymocytes for visualization of $\mathrm{CD} 4 / \mathrm{CD} 8$ double-negative (DN), CD4 single-positive $\left(\mathrm{CD} 4^{+} \mathrm{SP}\right), \mathrm{CD} 8$ single-positive $\left(\mathrm{CD} 8^{+} \mathrm{SP}\right)$ and $\mathrm{CD} 4 / \mathrm{CD} 8$ double-positive $\left(\mathrm{CD} 4^{+} / \mathrm{CD} 8^{+} \mathrm{DP}\right) \mathrm{T}$ cells (right). (B) tdT expression analysis (left) of the gated thymocytes (see a left) and CD4/CD8 plots for individual $\mathrm{CD} 4 / \mathrm{CD} 8$ expression analyses of $\mathrm{tdT}^{\text {neg }}$ (middle) and $\mathrm{tdT}^{+}$thymocytes (right). $\mathrm{tdT}^{\text {neg }}$ thymocytes represent mainly $\mathrm{DN}$ and $\mathrm{CD} 4^{+} / \mathrm{CD}^{+}$DP T cells (middle), whereas nearly all $\mathrm{CD} 4^{+} \mathrm{SP}$ and $\mathrm{CD} 8^{+} \mathrm{SP}$ thymocytes are $\mathrm{tdT}^{+}$(right). 


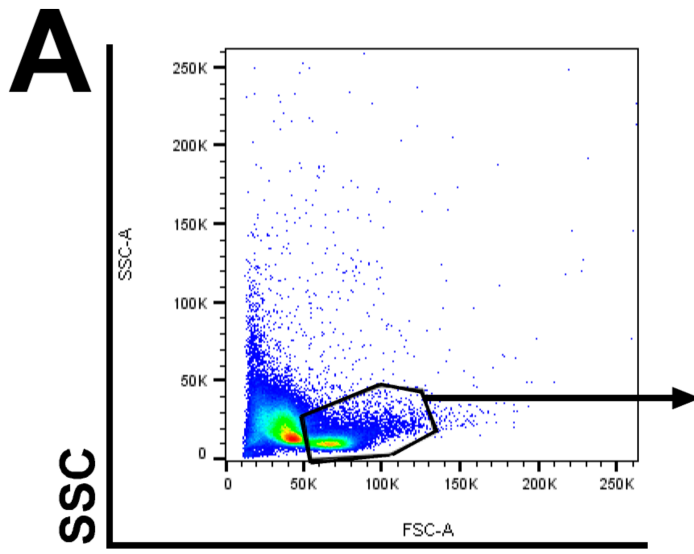

FSC

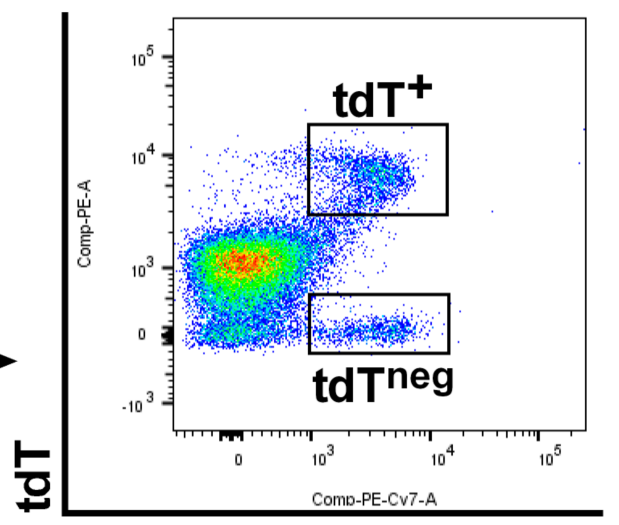

TCR $\beta$

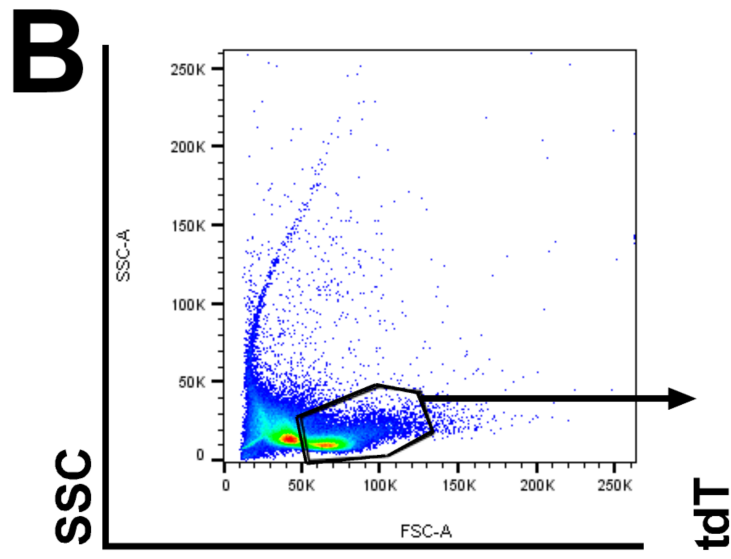

FSC

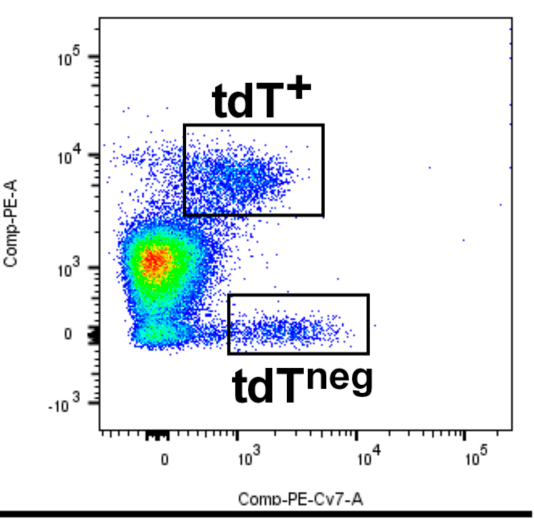

CD3

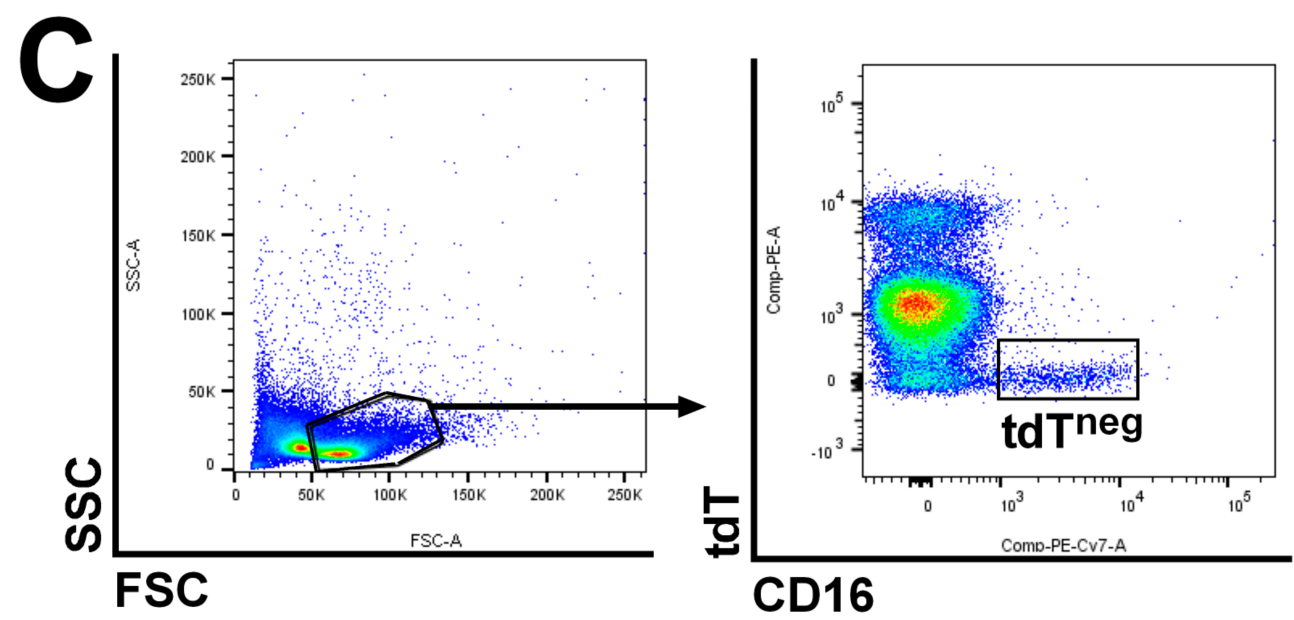

Figure A2. Flow cytometric analyses for the verification of antibody specificity. (A-C) Representative flow cytometric analyses of CD4Cre R26-tdT thymocytes stained with anti-CD4-FITC and (A) anti-TCR $\beta-P E-C y 7,(B)$ CD3-PE-Cy7 or (C) anti-CD16-PE-Cy7 antibodies. tdT was visualized using the PE channel. Left panels: FSC/SSC plots for gating on thymocytes. Right panels: individual tdT/TCR $\beta$ (A), tdT/CD3 (B) and tdT/CD16 (C) plots. The thymus of CD4Cre R26-tdT mice contains tdT ${ }^{+} \mathrm{TCR} \beta^{+}$ and $\mathrm{tdT}^{+} \mathrm{CD}^{+} \mathrm{T}$ cells but only a small fraction of $\mathrm{tdT}^{\text {neg }} \mathrm{CD} 16^{+}$cells (dendritic cells, natural killer cells, macrophages, monocytes and granulocytes). 
A

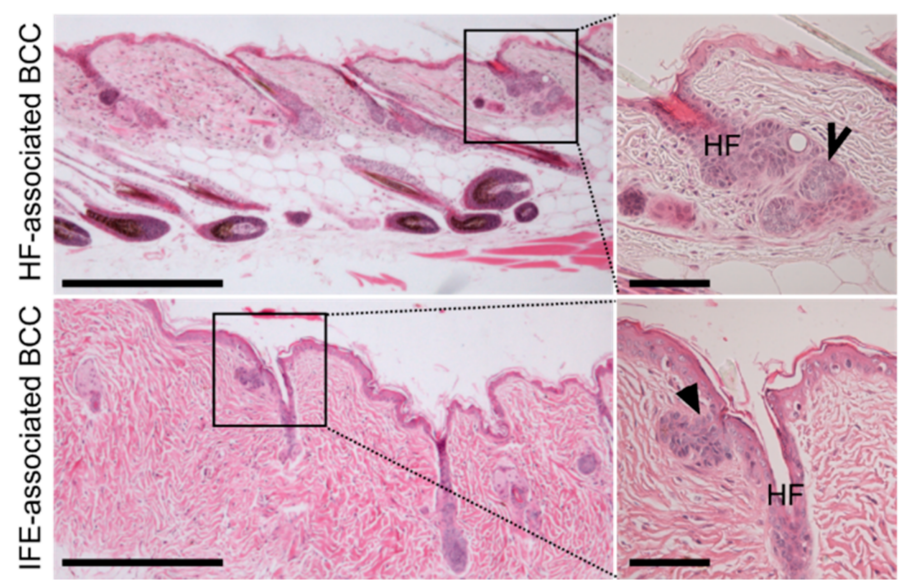

B

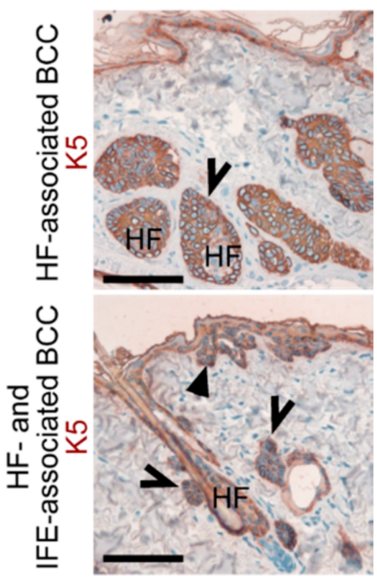

Figure A3. BCC-like tumors of Ptchfff K5CreERT skin arise from HF and IFE cells. (A,B) Representative (A) H\&E stainings and (B) anti-K5 antibody stainings of BCC from 28-37-week-old Ptch fff K5CreERT back skin $(N=5)$. Please note that the K5CreERT-deleter is leaky, and thus, BCC-like lesions also develop without tamoxifen induction [15]. Solid arrows: BCC associated to the IFE and open arrows: BCC associated to HF. HF, hair follicle. Boxes: zoomed areas. Scale bars: $20 \mu \mathrm{m}$ (A, left) and $100 \mu \mathrm{m}$ (A, right and B).

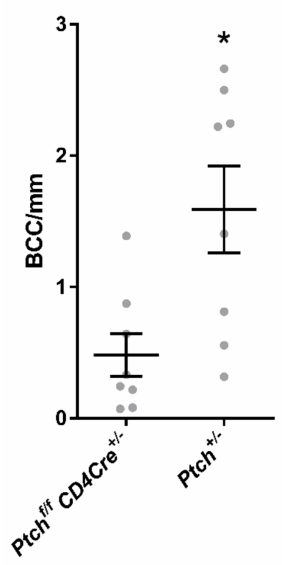

Figure A4. Comparison of BCC/mm skin in DMBA/TPA-treated Ptchfff $C D 4 C r e$ and Ptch ${ }^{+/-}$mice. BCC numbers per mm skin were counted from H\&E-stained paraffine sections of 8 DMBA/TPA-treated Ptchfff CD4Cre and 8 DMBA/TPA-treated $\mathrm{Ptch}^{+/-}$mice (each grey circle indicates the mean BCC number/mm of one animal). The significant difference was calculated using a nonparametric Mann-Whitney test. ${ }^{*} p>0.05$.
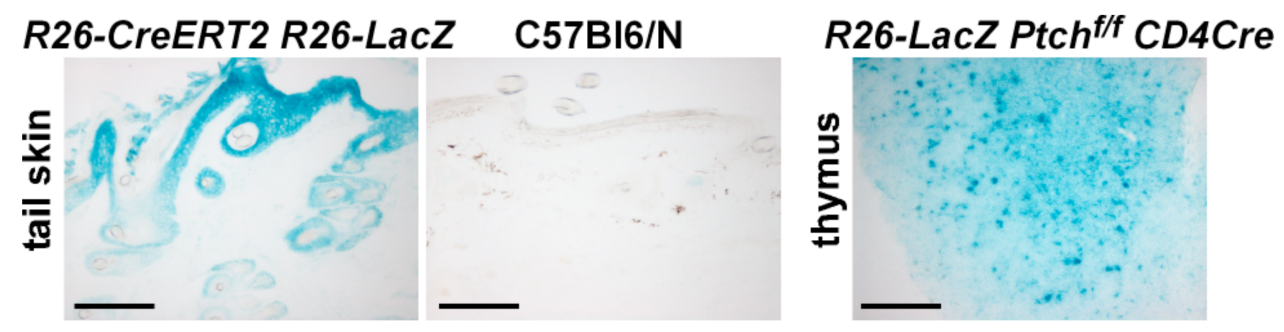

Figure A5. LacZ stainings of control tissues. Representative images of paraffin-sectioned LacZ-stained tail skin of a tamoxifen-treated R26-CreERT2 R26-LacZ (left, positive control) and a C57B16/N (middle, negative control) mouse, as well as of a R26-LacZ Ptchfff C D4Cre thymus (right, positive control). Scale bars: $100 \mu \mathrm{m}$. 


\section{References}

1. Grachtchouk, M.; Pero, J.; Yang, S.H.; Ermilov, A.N.; Michael, L.E.; Wang, A.; Wilbert, D.; Patel, R.M.; Ferris, J.; Diener, J.; et al. Basal Cell Carcinomas in Mice Arise from Hair Follicle Stem Cells and Multiple Epithelial Progenitor Populations. J. Clin. Investig. 2011, 121, 1768-1781. [CrossRef]

2. Lapouge, G.; Youssef, K.K.; Vokaer, B.; Achouri, Y.; Michaux, C.; Sotiropoulou, P.A.; Blanpain, C. Identifying the Cellular Origin of Squamous Skin Tumors. Proc. Natl. Acad. Sci. USA 2011, 108, 7431-7436. [CrossRef] [PubMed]

3. Wang, G.Y.; Wang, J.; Mancianti, M.-L.; Epstein, E. Basal Cell Carcinomas Arise from Hair Follicle Stem Cells in Ptch1+/- Mice. Cancer Cell 2011, 19, 114-124. [CrossRef] [PubMed]

4. Kasper, M.; Jaks, V.; Are, A.; Bergström, Å.; Schwäger, A.; Svärd, J.; Teglund, S.; Barker, N.; Toftgård, R. Wounding Enhances Epidermal Tumorigenesis by Recruiting Hair Follicle Keratinocytes. Proc. Natl. Acad. Sci. USA 2011, 108, 4099-4104. [CrossRef] [PubMed]

5. Peterson, S.C.; Eberl, M.; Vagnozzi, A.N.; Belkadi, A.; Veniaminova, N.A.; Verhaegen, M.E.; Bichakjian, C.K.; Ward, N.L.; Dlugosz, A.A.; Wong, S.Y. Basal Cell Carcinoma Preferentially Arises from Stem Cells Within Hair Follicle and Mechanosensory Niches. Cell Stem Cell 2015, 16, 400-412. [CrossRef]

6. Wong, S.Y.; Reiter, J.F. From the Cover: Wounding mobilizes hair follicle stem cells to form tumors. Proc. Natl Acad Sci USA 2011, 108, 4093-4098. [CrossRef] [PubMed]

7. Puig, S.; Berrocal, A. Management of High-Risk and Advanced Basal Cell Carcinoma. Clin. Transl. Oncol. 2015, 17, 497-503. [CrossRef] [PubMed]

8. Epstein, E. Basal Cell Carcinomas: Attack of the Hedgehog. Nat. Rev. Cancer 2008, 8, 743-754. [CrossRef]

9. Michel, K.D.; Uhmann, A.; Dressel, R.; Brandt, J.V.D.; Hahn, H.; Reichardt, H.M. The Hedgehog Receptor Patched1 in T Cells Is Dispensable for Adaptive Immunity in Mice. PLoS ONE 2013, 8, e61034. [CrossRef]

10. Uhmann, A.; Brandt, J.V.D.; Dittmann, K.; Heß, I.; Dressel, R.; Binder, C.; Lühder, F.; Christiansen, H.; Fassnacht, M.; Bhandoola, A.; et al. T Cell Development Critically Depends on Prethymic Stromal Patched Expression. J. Immunol. 2011, 186, 3383-3391. [CrossRef]

11. Uhmann, A.; Heß, I.; Frommhold, A.; König, S.; Zabel, S.; Nitzki, F.; Dittmann, K.; Lühder, F.; Christiansen, H.; Reifenberger, J.; et al. DMBA/TPA Treatment Is Necessary for BCC Formation from Patched Deficient Epidermal Cells in Ptch flox/Flox CD4Cre +/- Mice. J. Investig. Dermatol. 2014, 134, 2620-2629. [CrossRef] [PubMed]

12. Adolphe, C.; Hetherington, R.; Ellis, T.; Wainwright, B.; Thebault, S.; Flourakis, M.; Vanoverberghe, K.; Vandermoere, F.; Roudbaraki, M.; Lehen'Kyi, V.; et al. Patched1 Functions As a Gatekeeper by Promoting Cell Cycle Progression. Cancer Res. 2006, 66, 2081-2088. [CrossRef] [PubMed]

13. Adolphe, C.; Nieuwenhuis, E.; Villani, R.; Li, Z.J.; Kaur, P.; Hui, C.-C.; Wainwright, B. Patched 1 and Patched 2 Redundancy Has a Key Role in Regulating Epidermal Differentiation. J. Investig. Dermatol. 2014, 134, 1981-1990. [CrossRef] [PubMed]

14. Reeves, M.Q.; Kandyba, E.; Harris, S.; Del Rosario, R.; Balmain, A. Multicolour Lineage Tracing Reveals Clonal Dynamics of Squamous Carcinoma Evolution from Initiation to Metastasis. Nat. Cell Biol. 2018, 20, 699-709. [CrossRef]

15. Nitzki, F.; Becker, M.; Frommhold, A.; Schulz-Schaeffer, W.; Hahn, H. Patched Knockout Mouse Models of Basal Cell Carcinoma. J. Ski. Cancer 2012, 2012, 1-11. [CrossRef]

16. Pyczek, J.; Khizanishvili, N.; Kuzyakova, M.; Zabel, S.; Bauer, J.; Nitzki, F.; Emmert, S.; Schön, M.P.; Boukamp, P.; Schildhaus, H.-U.; et al. Regulation and Role of GLI1 in Cutaneous Squamous Cell Carcinoma Pathogenesis. Front. Genet. 2019, 10, 1185. [CrossRef]

17. Pellegrini, C.; Maturo, M.G.; Di Nardo, L.; Ciciarelli, V.; García-Rodrigo, C.G.; Fargnoli, M.C. Understanding the Molecular Genetics of Basal Cell Carcinoma. Int. J. Mol. Sci. 2017, 18, 2485. [CrossRef]

18. Tanimura, N.; Fujita, Y. Epithelial Defense against Cancer (EDAC). Semin. Cancer Biol. 2020, 63, 44-48. [CrossRef]

19. Kong, Y.-H.; Xu, S.-P. Salidroside Prevents Skin Carcinogenesis Induced by DMBA/TPA in a Mouse Model through Suppression of Inflammation and Promotion of Apoptosis. Oncol. Rep. 2018, 39, 2513-2526. [CrossRef]

20. Athar, M. Inhibition of Smoothened Signaling Prevents Ultraviolet B-Induced Basal Cell Carcinomas through Regulation of Fas Expression and Apoptosis. Cancer Res. 2004, 64, 7545-7552. [CrossRef] 
21. Biehs, B.; Dijkgraaf, G.J.P.; Piskol, R.; Alicke, B.; Boumahdi, S.; Peale, F.; Gould, S.E.; De Sauvage, F.J. A Cell Identity Switch Allows Residual BCC to Survive Hedgehog Pathway Inhibition. Nat. Cell Biol. 2018, 562, 429-433. [CrossRef] [PubMed]

22. Chaudhary, S.C.; Tang, X.; Arumugam, A.; Li, C.; Srivastava, R.K.; Weng, Z.; Xu, J.; Zhang, X.; Kim, A.L.; McKay, K.; et al. Shh and p50/Bcl3 Signaling Crosstalk Drives Pathogenesis of BCCs in Gorlin Syndrome. Oncotarget 2015, 6, 36789-36814. [CrossRef] [PubMed]

23. Kim, A.L.; Back, J.H.; Zhu, Y.; Tang, X.; Yardley, N.P.; Kim, K.J.; Athar, M.; Bickers, D.R. AKT1 Activation Is Obligatory for Spontaneous BCC Tumor Growth in a Murine Model That Mimics Some Features of Basal Cell Nevus Syndrome. Cancer Prev. Res. 2016, 9, 794-802. [CrossRef] [PubMed]

24. Zhu, G.A.; Sundram, U.; Chang, A.L.S. Two Different Scenarios of Squamous Cell Carcinoma within Advanced Basal Cell Carcinomas. JAMA Dermatol. 2014, 150, 970. [CrossRef] [PubMed]

25. Orouji, A.; Goerdt, S.; Utikal, J.; Leverkus, M. Multiple Highly and Moderately Differentiated Squamous Cell Carcinomas of the Skin during Vismodegib Treatment of Inoperable Basal Cell Carcinoma. Br. J. Dermatol. 2014, 171, 431-433. [CrossRef] [PubMed]

26. Aasi, S.; Silkiss, R.; Tang, J.Y.; Wysong, A.; Liu, A.; Epstein, E.; Oro, A.E.; Chang, A.L.S. New Onset of Keratoacanthomas after Vismodegib Treatment for Locally Advanced Basal Cell Carcinomas: A Report of 2 Cases. JAMA Dermatol. 2013, 149, 242-243. [CrossRef] [PubMed]

27. Zhao, X.; Ponomaryov, T.; Ornell, K.J.; Zhou, P.; Dabral, S.K.; Pak, E.; Li, W.; Atwood, S.X.; Whitson, R.J.; Chang, A.L.S.; et al. RAS/MAPK Activation Drives Resistance to Smo Inhibition, Metastasis, and Tumor Evolution in Shh Pathway-Dependent Tumors. Cancer Res. 2015, 75, 3623-3635. [CrossRef] [PubMed]

28. Wang, N.J.; Sanborn, Z.; Arnett, K.L.; Bayston, L.J.; Liao, W.; Proby, C.M.; Leigh, I.M.; Collisson, E.A.; Gordon, P.B.; Jakkula, L.; et al. Loss-of-Function Mutations in Notch Receptors in Cutaneous and Lung Squamous Cell Carcinoma. Proc. Natl. Acad. Sci. USA 2011, 108, 17761-17766. [CrossRef]

29. Pickering, C.R.; Zhou, J.H.; Lee, J.J.; Drummond, J.A.; Peng, S.A.; Saade, R.E.; Tsai, K.Y.; Curry, J.L.; Tetzlaff, M.T.; Lai, S.Y.; et al. Mutational Landscape of Aggressive Cutaneous Squamous Cell Carcinoma. Clin. Cancer Res. 2014, 20, 6582-6592. [CrossRef]

30. Dong, X.; Meng, L.; Liu, P.; Ji, R.; Su, X.; Xin, Y.; Jiang, X. YAP/TAZ: A Promising Target for Squamous Cell Carcinoma Treatment. Cancer Manag. Res. 2019, 11, 6245-6252. [CrossRef]

31. Kato, H.; Kurosawa, K.; Inoue, Y.; Tanuma, N.; Momoi, Y.; Hayashi, K.; Ogoh, H.; Nomura, M.; Sakayori, M.; Kakugawa, Y.; et al. Loss of Protein Phosphatase 6 in Mouse Keratinocytes Increases Susceptibility to Ultraviolet-B-Induced Carcinogenesis. Cancer Lett. 2015, 365, 223-228. [CrossRef] [PubMed]

32. Lynch, M.D.; Lynch, C.N.S.; Craythorne, E.; Liakath-Ali, K.; Mallipeddi, R.; Barker, J.N.; Watt, F.M. Spatial Constraints Govern Competition of Mutant Clones in Human Epidermis. Nat. Commun. 2017, 8, 1119. [CrossRef]

33. Wolfer, A.; Bakker, T.; Wilson, A.; Nicolas, M.; Ioannidis, V.; Littman, D.R.; Wilson, C.B.; Held, W.; Macdonald, H.R.; Radtke, F. Inactivation of Notch1 in Immature Thymocytes Does Not Perturb CD4 or CD8 T Cell Development. Nat. Immunol. 2001, 2, 235-241. [CrossRef] [PubMed]

34. Lee, P.P.; Fitzpatrick, D.R.; Beard, C.; Jessup, H.K.; Lehar, S.; Makar, K.W.; Pérez-Melgosa, M.; Sweetser, M.T.; Schlissel, M.S.; Nguyen, S.; et al. A Critical Role for Dnmt1 and DNA Methylation in T Cell Development, Function, and Survival. Immun. 2001, 15, 763-774. [CrossRef]

35. Sawada, S.; Scarborough, J.D.; Killeen, N.; Littman, D.R. A Lineage-Specific Transcriptional Silencer Regulates CD4 Gene Expression During T Lymphocyte Development. Cell 1994, 77, 917-929. [CrossRef]

36. Indra, A.K.; Warot, X.; Brocard, J.; Bornert, J.-M.; Xiao, J.-H.; Chambon, P.; Metzger, D. Temporally-Controlled Site-Specific Mutagenesis in the Basal Layer of the Epidermis: Comparison of the Recombinase Activity of the Tamoxifen-Inducible Cre-ERT and Cre-ERT2 Recombinases. Nucleic Acids Res. 1999, 27, 4324-4327. [CrossRef]

37. Madisen, L.; Zwingman, T.A.; Sunkin, S.M.; Oh, S.W.; Zariwala, H.A.; Gu, H.; Ng, L.L.; Palmiter, R.D.; Hawrylycz, M.J.; Jones, A.R.; et al. A Robust and High-Throughput Cre Reporting and Characterization System for the Whole Mouse Brain. Nat. Neurosci. 2010, 13, 133-140. [CrossRef]

38. Soriano, P. Generalized LacZ Expression With the ROSA26 Cre Reporter Strain. Nat. Genet. 1999, $21,70-71$. [CrossRef] 
39. Ventura, A.; Kirsch, D.G.; McLaughlin, M.E.; Tuveson, D.A.; Grimm, J.; Lintault, L.; Newman, J.C.J.; Reczek, E.E.; Weissleder, R.; Jacks, T. Restoration of p53 Function Leads to Tumour Regression in Vivo. Nat. Cell Biol. 2007, 445, 661-665. [CrossRef]

40. Okabe, M.; Ikawa, M.; Kominami, K.; Nakanishi, T.; Nishimune, Y. 'Green mice' As a Source of Ubiquitous Green Cells. FEBS Lett. 1997, 407, 313-319. [CrossRef]

41. Hahn, H.; Wojnowski, L.; Zimmer, A.M.; Hall, J.; Miller, G.; Zimmer, A. Rhabdomyosarcomas and Radiation Hypersensitivity in a Mouse Model of Gorlin Syndrome. Nat. Med. 1998, 4, 619-622. [CrossRef] [PubMed]

42. Uhmann, A.; Dittmann, K.; Nitzki, F.; Dressel, R.; Koleva, M.; Frommhold, A.; Zibat, A.; Binder, C.; Adham, I.; Nitsche, M.; et al. The Hedgehog Receptor Patched Controls Lymphoid Lineage Commitment. Blood 2007, 110, 1814-1823. [CrossRef] [PubMed]

43. Braun, K.M.; Niemann, C.; Jensen, U.B.; Sundberg, J.P.; Silva-Vargas, V.; Watt, F.M. Manipulation of Stem Cell Proliferation and Lineage Commitment: Visualisation of Label-Retaining Cells in Wholemounts of Mouse Epidermis. Dev. 2003, 130, 5241-5255. [CrossRef] [PubMed]

44. Sequeira, I.; Legue, E.; Capgras, S.; Nicolas, J.-F. Microdissection and Visualization of Individual Hair Follicles for Lineage Tracing Studies. Advanced Structural Safety Studies 2013, 1195, 247-258. [CrossRef]

45. Pyczek, J.; Buslei, R.; Schult, D.; Hölsken, A.; Buchfelder, M.; Heß, I.; Hahn, H.; Uhmann, A. Hedgehog Signaling Activation Induces Stem Cell Proliferation and Hormone Release in the Adult Pituitary Gland. Sci. Rep. 2016, 6, 24928. [CrossRef]

46. Dräger, J.; Simon-Keller, K.; Pukrop, T.; Klemm, F.; Wilting, J.; Sticht, C.; Dittmann, K.; Schulz, M.; Leuschner, I.; Marx, A.; et al. LEF1 Reduces Tumor Progression and Induces Myodifferentiation in a Subset of Rhabdomyosarcoma. Oncotarget 2017, 8, 3259-3273. [CrossRef]

Publisher's Note: MDPI stays neutral with regard to jurisdictional claims in published maps and institutional affiliations. 